\title{
KEBUTUHAN PROTEIN PAKAN UNTUK PERFORMA OPTIMAL BENIH IKAN PATIN PASUPATI (PANGASIID)
}

\author{
Evi Tahapari" dan Jadmiko Darmawan*) \\ *) Balai Riset Pemuliaan Ikan \\ (Naskah diterima: 25 September 2017; Revisi final: 8 Januari 2018; Disetujui publikasi: 8 Januari 2018)
}

\begin{abstract}
ABSTRAK
Penelitian ini bertujuan untuk mendapatkan kandungan protein optimum pakan untuk menunjang pertumbuhan maksimal dalam pemeliharaan benih ikan patin pasupati. Penelitian dirancang menggunakan rancangan acak lengkap (RAL) dengan empat perlakuan dan tiga ulangan. Sebagai perlakuan adalah pakan dengan kandungan protein berbeda, yaitu: A. 30\% B. 35\% C. 40\% dan D. 45\% Wadah pemeliharaan ikan uji adalah bak fiber berukuran $57 \mathrm{~cm} \times 36 \mathrm{~cm} \times 29 \mathrm{~cm}$. Sebanyak 30 ekor ikan uji berukuran bobot awal 0,94 $\pm 0,13 \mathrm{~g}$ dengan panjang awal 3,82 $\pm 0,21 \mathrm{~cm}$; ditebar ke dalam setiap bak. Percobaan berlangsung selama empat puluh hari. Ikan diberi pakan lima kali/hari sebanyak 10\%dari biomassa ikan. Parameter yang diamati adalah laju pertumbuhan bobot, pertumbuhan panjang, retensi protein, rasio konversi pakan, dan sintasan. Data dianalisis dengan analisis ragam pada selang kepercayaan $95 \%$ dan dilanjutkan dengan Uji Beda Nyata Terkecil (Uji BNT). Hasil penelitian menunjukkan bahwa pakan dengan kandungan protein 40\% (perlakuan C) memberikan performa pertumbuhan bobot, pertambahan panjang, retensi protein, dan konversi pakan terbaik $(P<0,05)$ dibandingkan dengan perlakuan lainnya. Sintasan ikan pada perlakuan $A$, B, dan C berturut-turut sebesar $81,11 \% 80,00 \%$ dan $80,00 \%$ dan tidak berbeda nyata ( $P>0,05)$. Ikan pada perlakuan D memiliki sintasan terendah yaitu $72,22 \%$
\end{abstract}

\section{KATA KUNCl: kebutuhan protein; performa pertumbuhan; patin pasupati}

\section{ABSTRACT: Dietary protein requirement for optimal performance of pasupati catfish seeds (Pangasiid). By: Evi Tahapari and Jadmiko Darmawan}

This study was aimed to determine the optimum feed protein content to support maximum growth performance of catfish juveniles. The study was designed using a completely randomized design (CRD) with four treatments and three replications. The treatments consisted of different protein contents of artificial feed, namely: A. 30\% B. 35\% C. 40\% and D. $45 \%$ The test fish were reared in fiber tank containers sized $57 \mathrm{~cm} \times 36 \mathrm{~cm} \times 29 \mathrm{~cm}$. A total of 30 fish with an initial weight of $0.94 \pm 0.13 \mathrm{~g}$ and length of $3.82 \pm 0.21 \mathrm{~cm}$ were stocked into each tank. The experiment lasted for forty days. Fish were fed with the experimental feeds five times/day as much as $10 \%$ of the fish biomass. The parameters observed were weight growth rate, growth length, protein retention, feed conversion ratio, and survival rate. The data were analyzed by analysis of varianceat $95 \%$ confidence interval and continued with the least significant difference (LSD) test. The results showed that the feed with a crude protein content of $40 \%$ (treatment C) gavethe best growth performance, protein retention and feed conversion and significantly different compared with the other treatments $(P<0.05)$. The survival rate of fish in treatment $A, B$, and $C$ were $81.11 \% 80.00 \%$ and $80.00 \%$ respectively which was not significantly different $(P>0.05)$. Fish in the treatment $D$ had the lowest survival rate $(72.22 \%)$.

\section{KEYWORDS: protein requirement; growth performance; pasupati catfish}

\section{PENDAHULUAN}

Ikan patin pasupati merupakan hibrida hasil persilangan antara betina patin siam (Pangasianodon hypophthalmus) dan jantan patin jambal (Pangasius

\footnotetext{
\# Korespondensi: Balai Riset Pemuliaan Ikan, Sukamandi. J.. Raya 2 Sukamandi, Subang, Jawa Barat 41256, Indonesia. Tel. + 62260520500

E-mail: evitahapari@yahoo.co.id
}

djambal). Ikan patin pasupati memiliki daging yang berwarna putih menyerupai ikan patin jambal dan lebih baik daripada daging ikan patin siam yang berwarna kekuningan. Harga ikan patin daging putih di pasar ekspor lebih tinggi dan lebih diminati daripada yang berwarna kekuningan (Legendre et al., 2000; Binh, 2006). Selain itu, ikan patin pasupati memiliki laju pertumbuhan yang tinggi (Gustiano et al., 2012). Ikan patin pasupati disukai konsumen karena berdaging 
putih dan memiliki tekstur daging lebih lembut, serta rasa lebih gurih dibandingkan dengan ikan patin siam yang memiliki warna daging kuning kemerahan. Perkembangan budidaya ikan patin pasupati terus meningkat sejalan meningkatnya permintaan ekspor. Dalam konteks perkembangan tersebut diperlukan antisipatif penyediaan benih untuk mendukung keberlanjutan kegiatan pada fase pembesaran.

Secara umum salah satu faktor produksi yang harus tersedia dalam kegiatan budidaya ikan adalah ketersediaan pakan berkualitas. Pakan merupakan faktor penting yang dapat mendukung keberhasilan dan keberlanjutan usaha. Biaya produksi dari komponen pakan relatif tinggi, diperkirakan mencapai $70 \% 90 \%$ dari total biaya operasional usaha (Da et al., 2011; Hung et al., 2007; Phuong et al., 2007). Perlu strategi penyediaan pakan yang cermat (kualitas dan kuantitas) untuk menekan biaya operasional usaha.

Protein merupakan salah satu nutrien penting dalam pakan. Protein sering kali digunakan sebagai indikator kualitas pakan. Pakan diperlukan untuk pertumbuhan, kesehatan ikan, dan untuk peningkatan mutu produksi. Untuk keperluan tersebut ikan memerlukan nutrien berupa protein yang kebutuhannya berbeda sesuai dengan umur dan jenis ikan. Sementara ini, kadar protein pakan yang digunakan pada pembenihan ikan patin pasupati di masyarakat masih beragam, berkisar 32\% 40\% Pemberian nutrien pakan yang tepat akan menghasilkan pertumbuhan dan efisiensi pakan yang optimal. Penelitian kebutuhan protein untuk pertumbuhan optimal pada patin siam dilaporkan oleh (Syamsunarno et al., 2011) pada ikan sepat (Trichogaster pectoralis) (Fran \& Akbar, 2013), pada juvenil ikan kerapu pasir (Epinephelus corallicola) (Marzuqi \& Anjusary, 2013). Protein merupakan sumber energi selain lemak dan karbohidrat bagi sintasan dan pertumbuhan ikan. Protein merupakan bahan yang mahal sehingga perlu kecermatan yang tinggi dalam penggunaannya. Dengan demikian, diperlukan informasi kebutuhan kadar protein optimum pakan dalam pemeliharaan benih ikan patin pasupati. Penelitian ini bertujuan untuk mendapatkan kandungan protein optimum pakan untuk menunjang pertumbuhan maksimal dalam pemeliharaan benih ikan patin pasupati.

\section{BAHAN DAN METODE}

Percobaan dilakukan di Balai Riset Pemuliaan Ikan Sukamandi mulai bulan Maret sampai September 2014. Percobaan dirancang menggunakan rancangan acak lengkap (RAL) terdiri atas empat perlakuan dan tiga ulangan. Sebagai perlakuan adalah perbedaan kadar protein dalam pakan, yaitu: A. $30 \%$ B. $35 \%$ C. $40 \%$ dan D. $45 \%$ Wadah pemeliharaan ikan uji adalah bak fiber berbentuk persegi panjang dengan ukuran 57 $\mathrm{cm} \times 36 \mathrm{~cm} \times 29 \mathrm{~cm}$ sebanyak 12 unit, dengan volume air $30 \mathrm{~L}$ yang dilengkapi dengan aerasi dan ditempatkan dalam ruangan. Benih ikan uji merupakan benih hasil pemijahan di unit Pembenihan Ikan Patin, Balai Riset Pemuliaan Ikan Sukamandi. Bobot benih ikan uji adalah $0,94 \pm 0,13 \mathrm{~g}$; dengan panjang total 3,82 $\pm 0,21 \mathrm{~cm}$ dan ditebar dengan kepadatan 30 ekor/bak.

Pakan percobaan diformulasi dengan bahan baku tepung bungkil kedelai, tepung ikan, dedak padi, tepung darah, tepung pollard, tepung bungkil kelapa, minyak ikan, tepung tapioca, dan premix. Empat pakan perco baan dibuat dengan kandungan protein berbeda, yaitu: 30\% 35\% 40\% dan 45\%(Tabel 1).

Parameter yang diamati meliputi laju pertumbuhan bobot (SGR), pertambahan panjang, retensi protein, konversi pakan, dan sintasan. Laju pertumbuhan spesifik dihitung dengan rumus Effendie (1997).

$$
\mathrm{SGR}=100 \times \frac{\left(\operatorname{LnW}_{t}-\mathrm{LnW}_{0}\right)}{\mathrm{t}}
$$

di mana:

SGR = laju pertumbuhan spesifik (\%hari)

$W_{t}=$ rata-rata bobot ikan pada akhir penelitian $(\mathrm{g})$

$\mathrm{W}_{0}=$ rata-rata bobot ikan pada awal penelitian $(\mathrm{g})$

$\mathrm{t}=$ lama pemeliharaan (hari)

Pertumbuhan panjang mutlak dihitung dengan menggunakan rumus Effendie (1997).

$$
\mathrm{L}=\mathrm{L}_{\mathrm{t}}-\mathrm{L}_{0}
$$

di mana:

$\mathrm{L} \quad=$ pertumbuhan panjang $(\mathrm{cm})$

$L_{L}=$ panjang rata-rata ikan pada akhir penelitian $(\mathrm{cm})$

$\mathrm{L}_{0} \quad=$ panjang rata-rata ikan pada awal penelitian $(\mathrm{cm})$

Retensi protein dihitung berdasarkan rumus Viola \& Rappaport (1979)

$$
\operatorname{RP}(\%)=\frac{(F-1)}{P} \times 100 \%
$$

di mana:

$\mathrm{RP}=$ retensi protein

$\mathrm{F}=$ jumlah protein tubuh pada akhir pemeliharaan $(\mathrm{g})$

$\mathrm{I}=$ jumlah protein tubuh pada awal pemeliharaan $(\mathrm{g})$

$\mathrm{P} \quad=$ jumlah protein pakan yang dikonsumsi ikan $(\mathrm{g})$

Rasio konversi pakan dapat dihitung dengan menggunakan rumus NRC (1983).

di mana:

$$
F C R=\frac{F}{\left(W_{t}+D\right)-W_{0}}
$$

$\mathrm{FCR}=$ feed convertion ratio atau rasio konversi pakan

$\mathrm{F} \quad=$ jumlah pakan yang diberikan selama penelitian $(\mathrm{g})$

$\mathrm{W}_{\mathrm{t}}=$ biomassa ikan pada akhir penelitian $(\mathrm{g})$

$\mathrm{W}_{0}=$ biomassa ikan pada awal penelitian ( $\mathrm{g}$ )

$D^{0}=$ biomassa ikan yang mati selama penelitian $(\mathrm{g})$ 
Tabel 1. Komposisi pakan percobaan (\%dalam pakan)

Table 1. Ingredients composition of experimental diets (\% of feed)

\begin{tabular}{lcccc}
\hline \multirow{2}{*}{$\begin{array}{c}\text { Bahan baku } \\
\text { Ingredients }\end{array}$} & \multicolumn{4}{c}{ Pakan percobaan (Test diets) } \\
\cline { 2 - 5 } & A & B & C & D \\
\hline Tepung bungkil kedelai (Soybean meal) & 15 & 23 & 30 & 35 \\
Tepung ikan (Fish meal) & 20 & 25 & 33 & 41 \\
Dedak padi (Rice bran) & 23 & 11 & 10 & 2 \\
Tepung darah (Blood meal) & 5 & 5 & 5 & 5 \\
Tepung pollar (Pollard meal) & 14 & 10 & 5 & 2 \\
Tepung bungkil kelapa (Coconut meal) & 14 & 17 & 8 & 6 \\
Minyak ikan (Fish oil) & 2 & 2 & 2 & 2 \\
Tepung tapioka (Tapioca flour) & 5 & 5 & 5 & 5 \\
Premix* & 2 & 2 & 2 & 2 \\
\hline \multicolumn{1}{c}{ Total } & $\mathbf{1 0 0}$ & $\mathbf{1 0 0}$ & $\mathbf{1 0 0}$ & $\mathbf{1 0 0}$ \\
\hline
\end{tabular}

*) Komposisi premix dalam jumlah $1 \mathrm{~kg}$ vit. A: 4.000 .000 IU, vit. D3: 800.000 IU, vit. E: $4.500 \mathrm{mg}$, vit. K3: $450 \mathrm{mg}$, vit. B1: $450 \mathrm{mg}$, vit. B2: $1.350 \mathrm{mg}$, vit. B6: $480 \mathrm{mg}$, vit. B12: $6 \mathrm{mg}$, Ca-d pantothenat: $2.400 \mathrm{mg}$, folic acid: 270 $\mathrm{mg}$, nicotinic acid: $7.200 \mathrm{mg}$, choline chlorida: $28.000 \mathrm{mg}$; mineral ferros: $8.500 \mathrm{mg}$, copper: $700 \mathrm{mg}$, manganese: $18.500 \mathrm{mg}$, zinc: $14.000 \mathrm{mg}$, cobalt: $50 \mathrm{mg}$, iodine: $70 \mathrm{mg}$, selenium: $35 \mathrm{mg}$

Sintasan dihitung dengan menggunakan rumus Effendie (1997).

$$
\mathrm{SR}=\frac{\mathrm{N}_{\mathrm{t}}}{\mathrm{N}_{\mathrm{o}}} 100 \%
$$

di mana:

$\mathrm{SR}=\operatorname{sintasan}(\%$

$N_{t}=$ jumlah ikan pada akhir penelitian (ekor)

$\mathrm{N}_{0}=$ jumlah ikan pada awal penelitian (ekor)
Sampling dilakukan setiap sepuluh hari sekali dengan mengukur sebanyak 15 ekor ikan dari setiap ulangan pada parameter bobot dan panjang ikan, kemudian dilakukan penyesuaian jumlah pakan yang diberikan berdasarkan biomassa ikan. Analisis proksimat pakan uji dan ikan percobaan dilakukan di Laboratorium Biologi Hewani, Institut Pertanian Bogor. Analisis proksimat pakan uji meliputi pengukuran kadar protein, lemak, serat kasar, dan air.

Tabel 2. Komposisi proksimat pakan percobaan (\%pakan)

Table 2. Proximate composition of test diets (\% of feed)

\begin{tabular}{|c|c|c|c|c|}
\hline \multirow{2}{*}{$\begin{array}{l}\text { Nutrien pakan } \\
\text { Nutrient feed }\end{array}$} & \multicolumn{4}{|c|}{ Perlakuan (Treatments ) } \\
\hline & $\begin{array}{c}A \\
(30)\end{array}$ & $\begin{array}{l}\text { B } \\
(35)\end{array}$ & $\begin{array}{c}C \\
(40)\end{array}$ & $\begin{array}{c}D \\
(45)\end{array}$ \\
\hline Protein kasar (Crude protein ) & 30.09 & 35.05 & 40.01 & 45.07 \\
\hline Lemak kasar (Crude lipid) & 3.25 & 4.77 & 5.64 & 7.28 \\
\hline Serat kasar (Crude fiber) & 8.54 & 5.58 & 4.25 & 5.03 \\
\hline Kadar air (M oisture) & 6.81 & 6.57 & 6.69 & 6.32 \\
\hline Energi total/GE (Total energy/GE) (kkal/kg)* & 4,432 & 4,296 & 4,280 & 4,304 \\
\hline Energi tercerna/DE (Digestible energy) (kkal/kg)** & 3,324 & 3,222 & 3,210 & 3,228 \\
\hline Rasio DE/P (Ratio DE/P) (kkal/g)**k & 11 & 9 & 8 & 7 \\
\hline \multicolumn{5}{|l|}{$\begin{array}{l}\text { Keterangan (Description): } \\
\text { *) } \\
\text { *) Energi total/GE, ditentukan dengan BOM kalorimeter } \\
\text { *) Energi tercerna (DE) }=75 \% \times \text { GE (Hepher, 1988) }\end{array}$} \\
\hline Rasio energi-protein $(D E / P)=\frac{D E}{10 \times \% \text { protein }}(H$ & & & & \\
\hline
\end{tabular}


Sedangkan analisis proksimat tubuh ikan meliputi pengukuran kadar protein, lemak, dan air. Pada awal penelitian diambil sebanyak 20 ekor ikan sampel dan pada akhir penelitian lima ekor ikan tiap ulangan untuk bahan analisis proksimat ikan. Analisis kadar air menggunakan meto de pemanasan dalam oven bersuhu $105^{\circ} \mathrm{C}-110^{\circ} \mathrm{C}$; serat kasar menggunakan metode pelarutan contoh dengan asam kuat, basa kuat, dan pemanasan; protein menggunakan metode Kjeldahl; lemak dengan menggunakan metode Soxchlet (Takeuchi, 1988).

Analisis data SGR, pertambahan panjang, retensi protein, rasio konversi pakan, dan sintasan menggunakan sidik ragam pada selang kepercayaan 95\% Jika dari hasil ANOVA terdapat berbeda nyata, maka dilanjutkan dengan uji beda nyata terkecil (uji BNT) dengan selang kepercayaan 95\%(Steel \& Torrie, 1981).

\section{HASIL DAN BAHASAN}

Bobot dan panjang ikan pada masing-masing perlakuan terjadi peningkatan. Perlakuan kandungan protein pakan berbeda memberikan pengaruh yang signifikan terhadap SGR, pertambahan panjang, retensi protein, rasio konversi pakan, dan sintasan ikan uji (Tabel 3).

Hasil evaluasi menunjukkan bahwa laju pertumbuhan spesifik (SGR) dan pertambahan panjang (L) berkisar 2,38\%3,63\% per hari dan 1,41-2,50 cm (Tabel 3). Nilai SGR ini lebih tinggi jika dibandingkan dengan hasil penelitian yang dilaporkan Triana (2004) bahwa benih patin siam dengan ukuran bobot awal 2,5-3,5 g yang diberi pakan dengan protein sebesar $35 \%$ 40\% dan $45 \%$ menghasilkan laju pertumbuhan spesifik 1,77\%2,90\%per hari. Pada percobaan ini bobot awal rata-rata individu sebesar 0,94 $\pm 0,13 \mathrm{~g}$; dan kemudian pada akhir penelitian berkisar antara 2,864,02 g (Gambar 1).
Hasil evaluasi menunjukkan pakan ikan dengan kandungan protein berbeda dapat memberikan pengaruh pada pertumbuhan ikan patin pasupati $(P<0,05)$. Pakan dengan kandungan protein $40 \%$ menghasilkan SGR tertinggi dan berbeda nyata $(P<0,05)$ dibandingkan perlakuan pakan lainnya. Kebutuhan protein pada ikan bervariasi tergantung spesies dan umur ikan. Beberapa penelitian melaporkan bahwa kebutuhan protein pada ikan baung Hemibagrus nemurus mencapai 31\% (Suhenda et al., 2010); ikan Tor tambroides sebesar 35\%dan 50\%(Radona et al., 2017) dan pada ikan snout bream M egalobrama amblycephala sebesar 35\% (Li et al., 2010). Protein merupakan zat pembangun jaringan otot dan daging, serta menjadi hormon dan enzim yang berperan dalam proses pertumbuhan. Namun demikian kebutuhan protein akan menurun dengan meningkatnya bobot dan umur ikan (Abdel-Tawwab et al., 2010; Arnason et al., 2010). Penggunaan protein sebagai sumber energi untuk aktivitas dan proses metabolisme ikan akan berakibat pada jumlah protein yang dimanfaatkan bagi pertumbuhan jaringan struktural juga berkurang sehingga berakibat pertumbuhan lambat (Kim \& Lee, 2005). Namun demikian protein yang berlebihan juga tidak akan efektif karena tidak akan termanfaatkan secara efisien dan protein termetabolisme sebagai energi (NRC, 2010; Hu et al., 2008). Penelitian serupa dikemukakan oleh Subamia et al. (2003) bahwa pakan dengan kadar protein 35\% dengan energi sebesar $2.987,5 \mathrm{kkal} / \mathrm{kg}$ pakan memberikan kinerja pertumbuhan optimum pada benih ikan patin jambal siam. Peningkatan protein pakan tidak selalu menyebabkan meningkatnya pertumbuhan ikan. Peningkatan protein pakan tan pa diikuti keseimbangan sumber energi non-protein akan menyebabkan protein digunakan sebagai sumber energi (Wilson, 1989). Terbukti bahwa pemberian tingkat protein pakan 45\% menghasilkan SGR dan pertambahan panjang yang lebih rendah dibandingkan dengan kandungan protein

Tabel 3. Performa ikan patin pasupati yang diberi pakan percobaan selama 40 hari

Table 3. Performance of pasupati catfish fed with the experimental diets for 40 days

\begin{tabular}{cccccc}
\hline $\begin{array}{c}\text { Pakan } \\
\text { percobaan } \\
\text { Test diets (\%) }\end{array}$ & $\begin{array}{c}\text { Laju pertumbuhan } \\
\text { spesifik (\%hari) } \\
\text { Spesific growth } \\
\text { rate (\%/day) }\end{array}$ & $\begin{array}{c}\text { Pertambahan } \\
\text { panjang } \\
\text { Lenght } \\
\text { increment (cm) }\end{array}$ & $\begin{array}{c}\text { Retensi } \\
\text { protein } \\
\text { Protein } \\
\text { retention (\%) }\end{array}$ & $\begin{array}{c}\text { Rasio } \\
\text { konversi pakan } \\
\text { Feed conversion } \\
\text { ratio }\end{array}$ & $\begin{array}{c}\text { Sintasan } \\
\text { Survival rate (\%) }\end{array}$ \\
\hline A (30) & $2.38 \pm 0.12^{\mathrm{a}}$ & $1.41 \pm 0.10^{\mathrm{a}}$ & $9.64 \pm 0.38^{\mathrm{a}}$ & $2.95 \pm 0.06^{\mathrm{c}}$ & $81.11 \pm 1.92^{\mathrm{b}}$ \\
$\mathrm{B}(35)$ & $2.84 \pm 0.12^{\mathrm{b}}$ & $1.96 \pm 0.10^{\mathrm{b}}$ & $11.49 \pm 1.01^{\mathrm{b}}$ & $2.29 \pm 0.14^{\mathrm{b}}$ & $80.00 \pm .3 .33^{\mathrm{b}}$ \\
C (40) & $3.63 \pm 0.11^{\mathrm{c}}$ & $2.50 \pm 0.10^{\mathrm{c}}$ & $14.04 \pm 0.72^{\mathrm{c}}$ & $1.80 \pm 0.06^{\mathrm{a}}$ & $80.00 \pm 3.33^{\mathrm{b}}$ \\
D (45) & $2.79 \pm 0.15^{\mathrm{b}}$ & $1.94 \pm .0 .05^{\mathrm{b}}$ & $11.31 \pm 1.11^{\mathrm{b}}$ & $2.33 \pm 0.02^{\mathrm{b}}$ & $72.22 \pm 1.92^{\mathrm{a}}$ \\
\hline
\end{tabular}

Keterangan: Nilai pada kolom yang diikuti huruf yang sama menunjukkan tidak berbeda nyata $(P>0,05)$

Description: The values in the same column followed by the same letter are not significantly different $(P>0.05)$ 


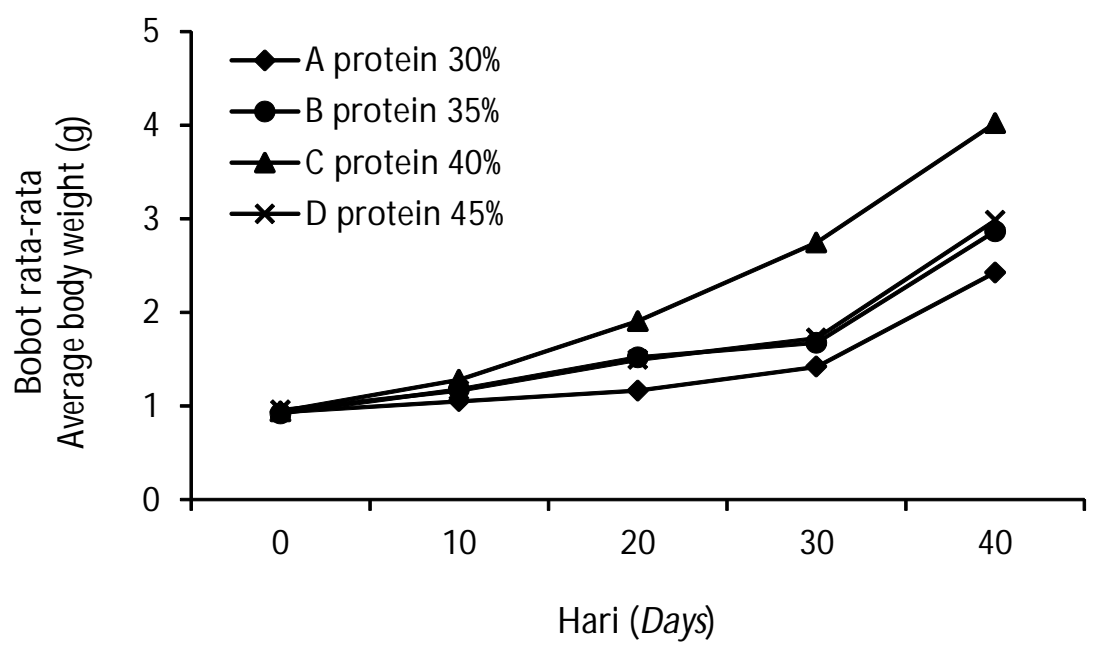

Gambar 1. Pola pertumbuhan bobot benih patin pasupati.

Figure 1. Growth pattern of pasupati catfish seed.

pakan $40 \%$ dan $35 \%$ Jika asupan protein dari pakan terlalu berlebihan, maka protein akan dirombak menjadi energi sehingga kelebihan protein menyebabkan meningkatnya kebutuhan energi untuk katabolisme protein yang berakibat meningkatkan SDA (Spesific Dynamic Action), yaitu penggunaan energi untuk merombak protein yang tidak digunakan untuk pertumbuhan. Demikian juga pemberian protein pakan rendah ( $30 \% 35 \%$ berakibat pula pada SGR dan $L$ yang relatif rendah. Rendahnya SGR dan L diduga karena keseimbangan energi-protein pakan tidak optimal. Keseimbangan energi dan protein pakan sangat berperan dalam menunjang pertumbuhan benih ikan. Pada penelitian ini pertumbuhan ikan terbaik diperoleh pada ikan yang diberi pakan dengan kadar protein $40 \%$ dan dengan rasio energi-protein sebesar $8 \mathrm{kkal} / \mathrm{g}$, dibandingkan dengan protein pakan 30\%dengan rasio energi-protein sebesar $11 \mathrm{kkal} / \mathrm{g}$ dan protein pakan $35 \%$ dengan rasio energi-protein sebesar $9 \mathrm{kkal} / \mathrm{g}$. Energi dalam pakan memengaruhi jumlah pakan yang dikonsumsi ikan (Smith, 1989).

Hasil analisis regresi hubungan antara pemberian protein pakan berbeda terhadap pertumbuhan bobot benih patin pasupati menunjukkan model regresi kubik (Gambar 2). Pertumbuhan bobot benih patin pasupati semakin meningkat hingga kandungan protein pakan optimum sebesar $40 \%$ kemudian menurun pada kandungan protein $45 \%$ Nilai $R^{2}=0,952$ menunjukkan adanya keeratan hubungan sebesar $95,2 \%$ antara perlakuan yang diberikan dengan respons yang dihasilkan.

Retensi protein pada percobaan ini berkisar $9,65 \%$ $14,04 \%$ (Tabel 3). Nilai retensi protein sangat nyata dipengaruhi oleh kadar protein pakan yang diberikan.
Perlakuan pakan $\mathrm{C}$ memiliki retensi protein tertinggi 14,04\% dibandingkan dengan perlakuan A, B, dan D secara berturut-turut 9,64\% 11,49\% dan $11,31 \%$ Penelitian sejenis dilaporkan Apriyanti (2010) pada ikan nila BEST dengan ukuran awal $10 \mathrm{~g}$ yang diberi pakan dengan kandungan protein 30\% dan pemberian Distiller's Dried Grain with Solubles (DDGS) dalam formulasi pakan sebesar 0\%, 5\% 10\% 15\% 20\% menghasilkan retensi protein berkisar 4,54\%7,32\% Pemanfaatan protein bagi pertumbuhan ikan dipengaruhi oleh beberapa faktor antara lain ukuran, umur, kualitas protein, kandungan energi pakan, suhu air, dan tingkat pemberian pakan (NRC, 1983). Tingginya retensi protein pada perlakuan $C$ menunjukkan protein pakan dapat dimanfaatkan lebih efisien oleh ikan sehingga laju pertumbuhan lebih tinggi dari pada perlakuan lainnya. Menurut Gaylord $\&$ Delbert (2001), bahwa konsumsi pakan dipengaruhi oleh kadar protein pakan sehingga berakibat pada nilai retensi protein ikan.

Hasil analisis regresi hubungan antara pemberian pakan dengan protein berbeda terhadap retensi protein benih patin pasupati menunjukkan model regresi kuadratik (Gambar 4).

Gambar 4 menunjukkan bahwa nilai retensi protein terus meningkat hingga optimum pada protein pakan $40 \%$ kemudian menurun pada tingkat protein pakan $45 \%$ Nilai $R^{2}=0,684$ menunjukkan adanya keeratan hubungan sebesar $68,4 \%$ antara perlakuan yang diberikan dengan respons yang dihasilkan.

Nilai rasio konversi pakan pada penelitian ini berkisar antara 1,80-2,95. Pakan perlakuan C memiliki nilai rasio konversi pakan terbaik 1,80 dibandingkan 


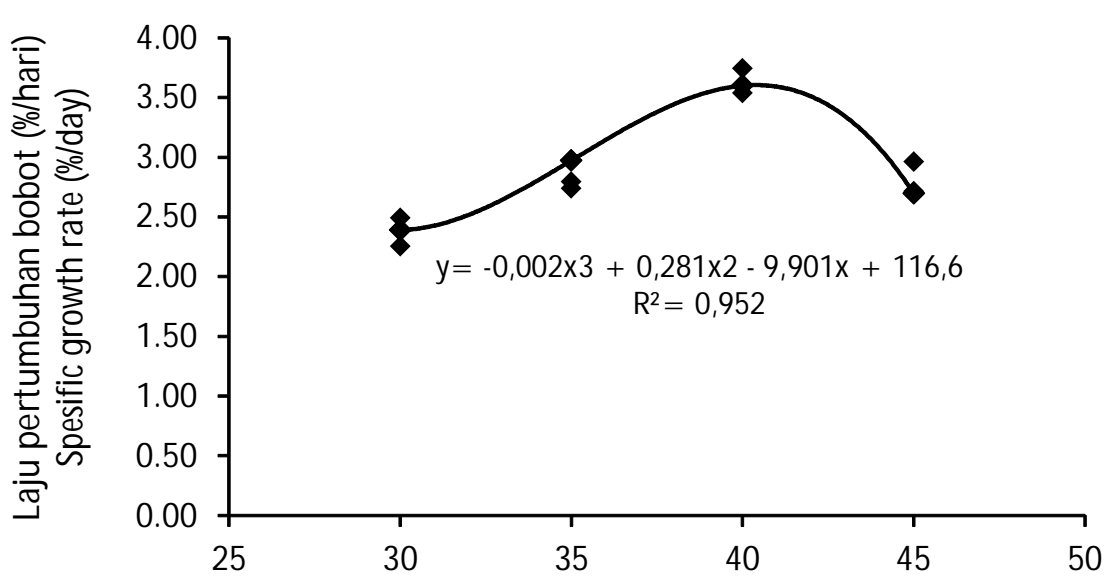

Kandungan protein pakan (Protein content of feed) $(\%$

Gambar 2. Hubungan kandungan protein pakan dan laju pertumbuhan bobot harian benih patin pasupati.

Figure 2. Correlation between various protein contents in feed and daily growth rate of pasupati catfish seed.

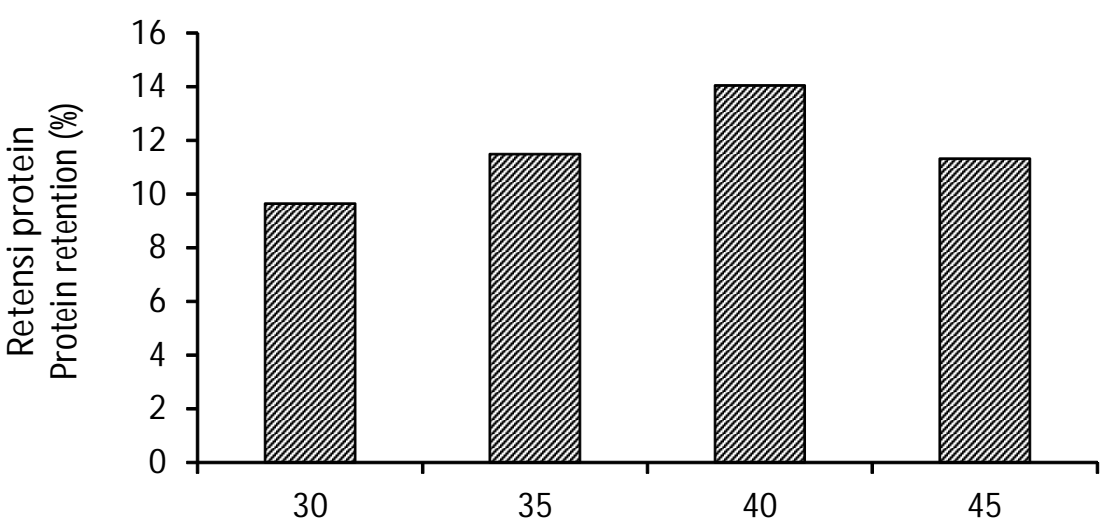

Kandungan protein pakan (Feed protein contents) (\%

Gambar 3. Retensi protein benih patin pasupati pada berbagai kandungan protein pakan percobaan.

Figure 3. Protein retention of pasupati catfish seed fed with various feed protein contents.

dengan perlakuan pakan lainnya (Tabel 3). Kebutuhan protein untuk ikan berbeda-beda tergantung spesiesnya dan pada umumnya berkisar $30 \% 40 \%$ (Jobling, 1994). Protein merupakan komponen penyusun tubuh yang utama dan terpenting dibandingkan karbohidrat dan lemak. Nilai rasio konversi pakan dipengaruhi oleh beberapa faktor di antaranya: kandungan nutrisi dan jumlah pakan yang diberikan, serta lingkungan budidaya. Nilai FCR pada penelitian ini relatif lebih tinggi dibandingkan dengan yang dilaporkan oleh Da et al. (2016) bahwa ikan patin siam (bobot awal; 16,5 $\pm 0,1 \mathrm{~g}$ ) yang dipelihara di kolam tanah dengan menggunakan wadah jaring yang diberi pakan buatan dengan kadar protein $22,7 \%$ memiliki nilai FCR 1,42-2,10 selama empat bulan pemeliharaan (Gambar 5).

Hasil analisis regresi hubungan tingkat protein pakan dengan rasio konversi pakan benih patin pasupati menunjukkan model regresi kubik (Gambar 6).

Gambar 6 menunjukkan bahwa rasio konversi pakan benih patin pasupati semakin rendah atau menurun hingga tingkat protein pakan yang optimum 


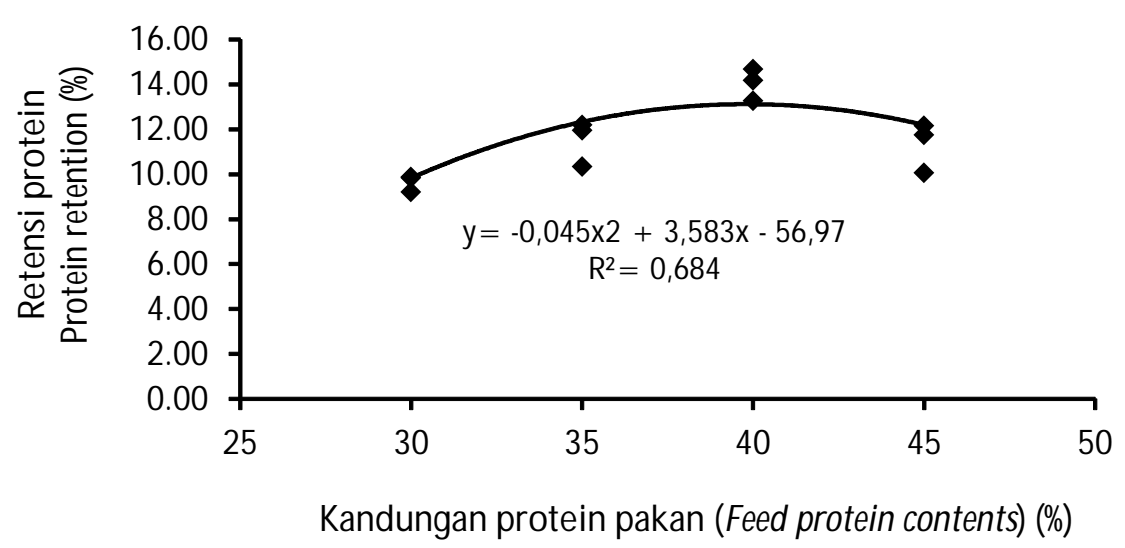

Gambar 4. Hubungan kandungan protein pakan dengan retensi protein benih patin pasupati.

Figure 4. Correlation between various protein contents in feed and protein retention of pasupati catfish seed.

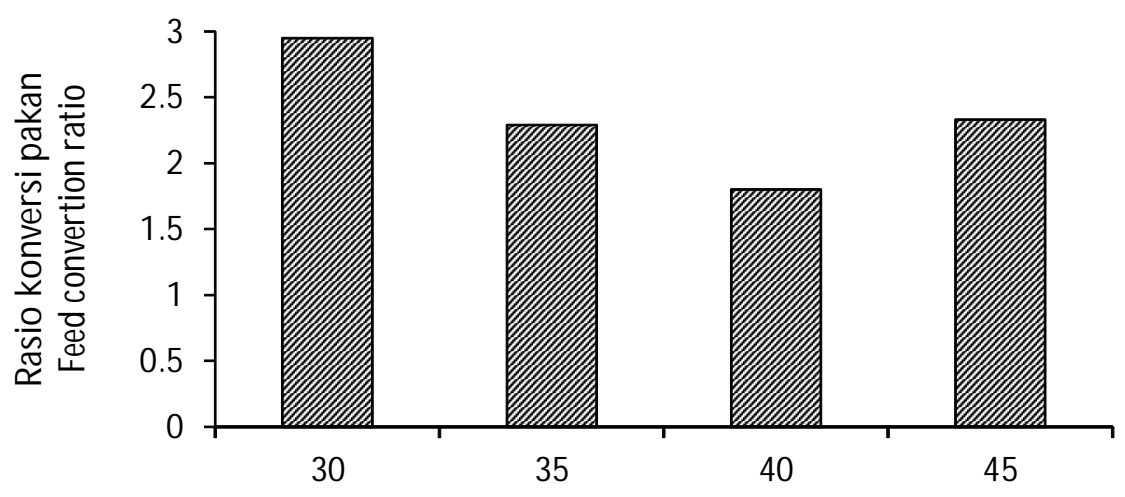

Kandungan protein pakan (Feed protein contents) $(\%$

Gambar 5. Grafik rasio konversi pakan benih patin pasupati pada berbagai kandungan protein pakan.

Figure 5. Feed conversion ratio of pasupati catfish seed fed with different protein contents of feed.

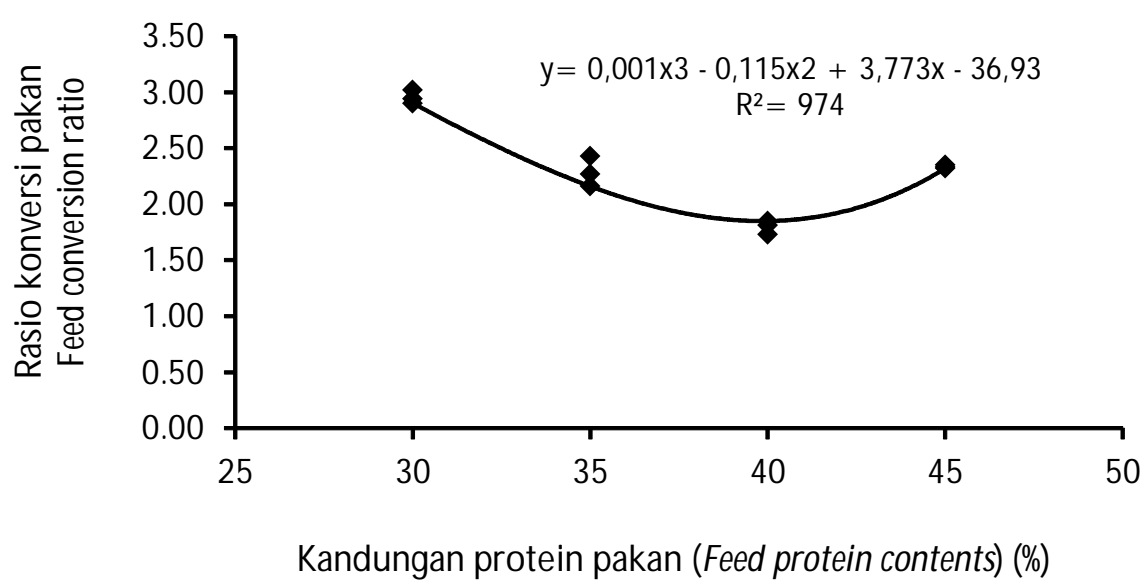

Gambar 6. Grafik regresi pengaruh berbagai kandungan protein pakan dengan rasio konversi pakan benih patin pasupati.

Figure 6. Regression effects of various protein contents of feed with feed conversion ratio of pasupati catfish seed 


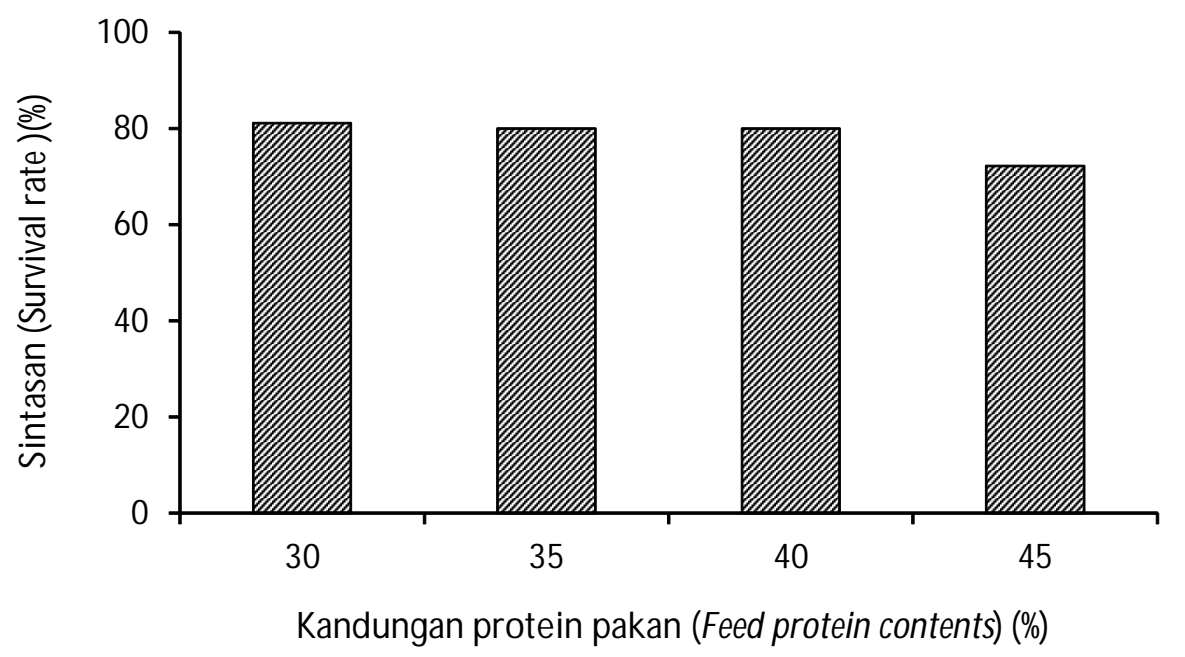

Gambar 7. Sintasan rata-rata benih patin pasupati pada berbagai kandungan protein pakan.

Figure 7. Average survival rate of pasupati catfish seed fed wit different feed protein contents of feed.

yaitu sebesar $40 \%$ tetapi meningkat kembali pada protein $45 \%$ Nilai $R^{2}=0,974$ menunjukkan adanya keeratan hubungan sebesar $97,4 \%$ antara perlakuan yang diberikan dengan respons yang dihasilkan.

Sintasan pada akhir penelitian berkisar $72,22 \%$ $81,11 \%$ Sintasan terendah pada perlakuan D sebesar $72,22 \% y a n g$ berbeda nyata dengan perlakuan lainnya $(P<0,05)$. Ikan mengonsumsi pakan untuk mempertahankan kelangsungan hidupnya dan selebihnya untuk pertumbuhan (NRC, 1983). Sintasan ikan pada perlakuan $D$ lebih rendah dibandingkan dengan perlakuan lainnya. Hal ini diduga karena kandungan rasio energi-protein dalam perlakuan pakan $D$ relatif rendah sebesar $7 \mathrm{kkal} D E / g$ protein dibandingkan dengan perlakuan pakan lainnya. Kondisi seperti ini akan berakibat pada protein dipecah dan digunakan sebagai sumber energi. Pemakaian protein sebagai sumber energi diduga akan menyebabkan sintasan dan pertumbuhan terhambat, mengingat pro tein sangat berperan dalam pembentukan sel baru. Semakin tingginya kadar protein melebihi kebutuhan optimal maka dikhawatirkan semakin banyak asam amino yang dikatabolisme. Deaminasi asam amino yang berlebihan dan terjadinya akumulasi asam amino bebas atau fraksi amino dapat menyebabkan kondisi toksik bagi ikan, sehingga dapat memengaruhi sintasan ikan (Cowey \& Sargent, 1985 dalam Sutandi, 2007).

\section{Kualitas Air}

Hasil pengukuran pada beberapa parameter kualitas air menunjukkan masih dalam kisaran yang optimal untuk pertumbuhan ikan (Boyd, 1990) (Tabel 4).

Tabel 4. Kisaran nilai parameter kualitas air

Table 4. Range of water quality parameter values

\begin{tabular}{cccccc}
\hline & \multicolumn{5}{c}{ Parameter (Parameters) } \\
\cline { 2 - 6 } $\begin{array}{c}\text { Perlakuan } \\
\text { Treatments }\end{array}$ & $\begin{array}{c}\text { Suhu } \\
\text { Temperature ('C) }\end{array}$ & $\mathbf{p H}$ & $\begin{array}{c}\text { Oksigen terlarut } \\
\text { Dissolved oxygen (mg/L) }\end{array}$ & $\begin{array}{c}\text { Amonia } \\
\text { Ammonia (mg/L) }\end{array}$ & $\begin{array}{c}\text { Nitrit } \\
\text { Nitrite (mg/L) }\end{array}$ \\
\hline A & $29.5-30.8$ & $7.41-8.10$ & $4.7-5.6$ & $0.0010-0.5726$ & $0.0009-0.5525$ \\
B & $29.5-30.7$ & $7.51-8.02$ & $5.1-5.9$ & $0.0008-0.3527$ & $0.0005-0.4018$ \\
C & $29.8-30.8$ & $7.25-8.05$ & $5.2-5.9$ & $0.0015-0.4925$ & $0.0007-0.4350$ \\
D & $29.9-30.8$ & $7.64-8.25$ & $4.8-5.9$ & $0.0027-0.7812$ & $0.0012-0.5312$ \\
\hline
\end{tabular}




\section{KESIMPULAN}

Kandungan protein pakan berpengaruh terhadap performa pertumbuhan bobot, panjang, retensi protein, dan rasio konversi pakan benih patin pasupati yang dipelihara secara indoor. Pakan dengan kandungan protein $40 \%$ memberikan performa terbaik terhadap laju pertambahan spesifik, partambahan panjang, retensi protein, dan konversi pakan benih patin pasupati.

\section{UCAPAN TERIMA KASIH}

Diucapkan terima kasih kepada Tatang Rustandi, Iksan Aulia, dan Arsyad selaku tim teknisi komoditas ikan patin Balai Riset Pemuliaan Ikan Sukamandi atas bantuan yang penuh tanggung jawab sehingga penelitian ini dapat terlaksana dengan baik.

\section{DAFTAR ACUAN}

Abdel-Tawwab, M., Ahmad, M., Khattab, Y.A.E., \& Shalaby, A.D.E. (2010). Effect of dietary protein level, initial body weight, and their interaction on the growth, feed utilization, and physiological alterations of nile tilapia, Oreochromis niloticus. Aquaculture, 298, 267-274.

Apriyanti, S. (2010). Pengaruh tingkat penggunaan Distiller's Dried Grain with Solubles (DDGS) pada formulasi pakan buatan terhadap pertumbuhan dan retensi protein ikan nila BEST (Oreochromis niloticus). Skripsi. Fakultas Perikanan dan IImu Kelautan, Universitas Padjadjaran.

Arnason, J., Bjornsdottir, R., Arnarsson, I., Arnadottir, G.S., \& Thorarensen, H. (2010). Protein requirements of atlantic cod Gadus morhua L. Aquaculture, 41, 385-393.

Binh, T.V. (2006). Before and after the catfish war: market analysis. Centre for ASEAN Studies. CAS Discussion Paper No. 50, 26 pp.

Boyd, C.E. (1990). Water quality in ponds for aquaculture. Alabama Agricultural Experiment Station. Auburn University. Alabama, p. 131-156.

Da, C.T., Hung, L.T., Berg, H., Lindberg, J.E., \& Lundh, T. (2011). Evaluation of potential feed sources, and technical and economic considerations of small-scale commercial striped catûsh (Pangasius hypophthalamus) pond farming systems in the Mekong Delta of Vietnam. Aquac. Res., 44, 427438.

Da, C.T., Lundh, T., Lindberg, J.E., Hung, L.T., \& Berg, H. (2016). Growth performance, feed utilisation and biological indices of Tra catûsh (Pangasianodon hypophthalmus) cultured in net cages in pond fed diets based on locally available feed resources. Aquac. Res., 8, 309-321.
Effendie, M.I. (1997). Biologi perikanan. Yogyakarta: Yayasan Pustaka Nusatama, $92 \mathrm{hlm}$.

Fran, S., \& Akbar, J. (2013). Pengaruh perbedaan tingkat protein dan rasio protein pakan terhadap pertumbuhan ikan sepat (Trichogaster pectoralis). Fish Scientiae, 3(5), 53-63.

Gaylord, T.G., \& Delbert, M.G.III. (2001). Dietary protein and energy modification to maximize compensatory growth of channel catfish (Ichtalurus punctatus). Aquaculture, 194, 337-348.

Gustiano, R., Kristanto, A.H., Tahapari, E., \& Iswanto, B. (2012). Evaluation of Pangasius djambal Bleeker 1846 and Pangasianodon hypophthalmus (Sauvage, 1878) hybrids: biometric, growth, and ovarian maturation. Buletin Plasma Nutfah, 18(1), 32-37.

Hepher, B. (1988). Nutrition of pond fishes. Cambridge: Cambridge University Press. New York, Sydney, $208 \mathrm{pp}$.

Hu, Y., Tan, B.P., Mai, K.S., Zheng, S., \& Cheng, K. (2008). Growth and body composition of juvenile white shrimp, Litopenaeus vannamei, fed different ratios of dietary protein to energy. Aquaculture Nutrition, 14, 499-506.

Hung, L.T., Truc, L.T.T., \& Huy, H.P.V. (2007). Case study on the use of farm-made feeds and commercially formulated pellets for pangasiid catûsh culture in the Mekong Delta, Vietnam: Study and analysis of feeds and fertilizers for sustainable aquaculture development. Food and Agriculture Organization of United Nattion, FAO. Fisheries Technical Paper, 497, 363-377.

Jobling, M. (1994). Fish bioenergetics. London: Chapman and Hall, 309 pp.

Kim, L.E., \& Lee, S.M. (2005). Effects of the dietary protein and lipid levels on growth and body composition of bagrid catfish, Pseudobagrus fulvidraco. Aquaculture, 243, 323-329.

Legendre, M., Pouyaud, L., Slembrouck, J., Gustiano, R., Kristanto, A,H., Subagja, J., Komarudin, O., Sudarto \& Maskur. (2000). Pangasius djambal: a new candidate species for fish culture in Indonesia. Indonesian Agricultural Research and Development Journal, 22(1), 1-14.

Li, X., Liu, W., Jiang, Y., Zhu, H., \& Ge, X. (2010). Effects of dietary protein and lipid levels in practical diets on growth performance and body composition of blunt snout bream Megalobrama amblycephala fingerlings. Aquaculture, 303, 65-70.

Marzuqi, M., \& Anjusary, D.N. (2013). Kecernaan nutrien pakan dengan kadar protein dan lemak berbeda pada juvenil ikan kerapu pasir (Epinephelus corallicola). Jurnal IImu dan Teknologi Kelautan Tropis, 5, 311-323. 
National Research Council [NRC]. (1983). Nutrient requirement of warmwater fishes and shelfishes revised edition. Washington D.C.: National Academy Press, 102 pp.

National Research Council [NRC]. (2010). Nutrient requirements of fish and shrimp. Washington: National Academies Press, 376 pp.

Phuong, N.T., Sinh, L.X., \& Thinh, N.Q. (2007). Economics of aquaculture feeding practices. Vietnam. FAO Fish Tech. Pap. Rome, 505, 183-205.

Radona, D., Subagja, J., \& Kusmini, I.I. (2017). Kinerja pertumbuhan dan efisiensi pakan ikan Tor tambroides yang diberi pakan komersial dengan kandungan protein berbeda. Media Akuakultur, 12(1), 27-33.

Syamsunarno, M.B., Mokoginta, I., \& Jusadi, D. (2011). Pengaruh berbagai rasio energi protein pada pakan iso protein $30 \%$ terhadap kinerja pertumbuhan benih ikan patin (Pangasius hypophthalmus). Jurnal Riset Akuakultur, 6(1), 63-70.

Smith, R.R. (1989). Nutritional energetics. In fish nutrition. New York: Academic Press Inc., p. 228.

Steel, R.G.D., \& Torrie, J.H. (1991). Principles and procedures of statistics. London: McGraw-Hill, Book Company, Inc., 772 pp.

Subamia, L.W.,. Suhenda, N., \& Tahapari. E. (2003). Pengaruh pemberian pakan buatan dengan kadar lemak yang berbeda terhadap pertumbuhan dan sintasan benih ikan jambal siam (Pangasius hypophthalmus). Jurnal Pen. Perik. Indonesia, 9(1), 37-42.

Suhenda, N., Samsudin, R., \& Melati, I. (2010). Peningkatan kualitas bahan nabati (dedak padi dan dedak polar) melalui proses fermentasi (Rhizopus oligosporus) dan penggunaannya dalam ikan mas (Cyprinus carpio). Prosiding Forum Inovasi Teknologi Akuakultur 2010, hIm. 689-695.

Sutandi, T. (2007). Pengaruh tingkat protein pakan terhadap kelangsungan hidup dan pertumbuhan benih lele dumbo (Clarias gariepinus Bur.) dalam karamba jaring apung Waduk Cirata. Skripsi. Fakultas Perikanan dan IImu Kelautan Universitas Padjadjaran. Jatinangor.

Takeuchi, T. (1988). Laboratory work chemical evaluation of dietary nutrients. In Watanabe, T. (Ed.). Fish Nutrition and Mariculture. Tokyo. Departement of Aquatic. Bioscience. Tokyo University of Fisheries, JICA, p. 179229.

Triana. (2004). Pengaruh kadar protein dan rasio energi protein pakan yang berbeda terhadap pertumbuhan benih jambal siam (Pangasius hypopthalmus). Skripsi. Fakultas Pertanian Universitas Padjadjaran. Jatinangor.

Viola, S., \& Rappaport, U.(1979). The "extra calorie effec" of oil in nutrient of carp. Bamidgeh, 31(3), 51-69.

Wilson, R.P. (1989). Amino acids and protein. In Halver, J.E. (Ed.). Fish Nutrition. New York: Academic Press Inc, p. 111-148. 